\title{
PERFORMANCE EVALUATION OF AN INVERTED DOWNDRAFT BIOMASS GASIFIER COOK-STOVE
}

\author{
Orisaleye, J. I. ${ }^{a}$, Adefuye, O. A..$^{b, *}$, Ogundare, A. A. ${ }^{a}$, \\ Fadipe, O. L $^{b}$, Ope, A. A. ${ }^{a}$ \\ ${ }^{a}$ Department of Mechanical Engineering, University of Lagos, Akoka, Nigeria \\ ${ }^{b}$ Department of Mechanical Engineering, Lagos State University, Epe Campus, Nigeria \\ *Corresponding author: olusegun.adefuye@lasu.edu.ng
}

Received: $16^{\text {th }}$ November 2017

Accepted: $8^{\text {th }}$ January 2018

Published: $16^{\text {th }}$ March 2018

https://doi.org/10.47545/etrj.2018.3.1.039

\begin{abstract}
The use of biomass is becoming increasingly important as an alternative energy resource, particularly for developing countries. The conversion of solid biomass to gaseous forms by the use of gasifiers has some prospects for domestic and industrial utilization. Improved cook-stoves based on gasification are considered to be costeffective means of energy supply to households for cooking. In this study, four biomass fuels - wood chips, corn cobs, coconut shells and palm kernel shells - were characterized and used to carry out a performance evaluation of an inverted downdraft biomass gasifier cook-stove. The performance evaluation showed that all fuels used were suitable for the operation of the cook-stove with wood chips having the best performance. The efficiency of the stove varied with the fuel used with the maximum efficiency of the cook-stove being $20.76 \%$. The fuel consumption rate of the cook-stove for utilization of the biomass fuels ranged between 1.60 to $1.82 \mathrm{~kg} / \mathrm{hr}$. The specific gasification rate also ranged between 85.89 and $102.25 \mathrm{~kg} / \mathrm{m}^{2} \mathrm{hr}$.
\end{abstract}

Keywords: biomass, cook-stove, inverted downdraft gasifier, proximate analysis, energy.

\section{INTRODUCTION}

Biomass energy exists in great abundance globally. Some studies have been carried out on the potential of biomass energy globally and regionally [1-4]. Over 50\% of the energy used in developing countries is utilized for domestic cooking and $75 \%$ of populace in developing countries employ inefficient traditional cook-stoves. Cooking is responsible for around 5\% of all green-house gas emissions worldwide and around 50\% of energy for solid-fuel cooking could be saved with very low costs and high net benefits by switching to energy efficient cooking appliances [5].

The World Health Organization stated that air pollution due to inefficient use of solid fuels has resulted in deaths resulting from pneumonia, stroke, heart disease, chronic obstructive pulmonary disease and lung cancer [6]. Benefits of improved cook-stoves have been outlined to include saving of fuels and, directly or indirectly, saving time due to the stoves' higher thermal efficiency; more complete combustion which makes the kitchen a healthier place in which to work; and reduction in safety hazards such as less exposure to heat resulting in a better work environment [7].

The emergence of perennial fuel crisis has drawn attention to the need for energy experts to concentrate on producing viable alternatives and/or compliments to kerosene and cooking gas for domestic cooking [8]. Some work has been done in developing alternatives using biomass conversion methods like biomass briquettes [9, 10], gasification [11] and biogas [12] to ensure clean and better burning of fuels suitable for energy generation. Gasification seems to hold some promise for producing energy for domestic cooking. Also, interests have developed in improving biomass cook-stoves to protect the health of women who are usually the users of the inefficient biomass cook-stoves.

A study by [13] developed a biomass cook-stove and used wood shavings as fuel. The fuel conversion rate of the stove was $1.89 \mathrm{~kg} / \mathrm{hr}$ with a thermal efficiency of $10.6 \%$. Study [14] tested a biomass wood stove with Amla calotropis, Juliflora, neem wood and cashew nut shell and found that the thermal efficiency of neem wood was $56 \%$ higher than other biomass materials. Study [15] also developed a biomass gasifier stove with specific fuel 
consumption of $1.3 \mathrm{~kg} / \mathrm{hr}$ and a thermal efficiency of $17.2 \%$. An improved wood stove which had thermal efficiency reaching $64.4 \%$ and power delivery of $2.52 \mathrm{~kW}$ was designed in study [16].

In study [17], a biomass cook-stove was fabricated with a power output of $1.5 \mathrm{~kW}$ and it was observed that the thermal efficiency of the cook-stove is a function of the fuel burning rate, amount of primary and secondary air, and draft between top and bottom of the combustion chamber. Study [18] also developed and evaluated the performance of a biomass gasifier stove for domestic purposes which was reported to have an efficiency of $30 \%$. A supplemental air-supplied charcoal stove which had an efficiency of $36.74 \%$ as also been designed [19].

The effects of five different configurations of natural draft semi-gasifier stoves and different biomass fuels on the performance of the stoves were determined by [20]. The study concluded that emissions varied substantially with stove geometry and the fuel type. It was opined by [21] that the design of more efficient wood using appliances has the potential to reduce particulate matter exposure and designed a natural draft wood gasification stove based on inverted downdraft principle.

Study [22] investigated the performance of a top-lit updraft cook-stove using wood chips, coconut shell and rice husk briquettes using a water boiling test and controlled cooking test. The study observed that the cook-stove was significantly influenced by the type of fuel used. The performance of the cook-stove was best when wood chips were used followed by rice husk briquettes and coconut shell. Other cook-stoves have been reviewed by [23] and [24].

For effective dissemination and utilization of the biomass cook-stove, the stove must be able to operate using locally available biomass which could be readily sourced. The performance evaluation of an inverted downdraft biomass cook-stove was carried out in this study using some common agricultural waste resources in Nigeria.

\section{DESIGN OF BIOMASS COOK-STOVE}

The biomass cook-stove consist of the reactor, the burner and the ash collector. Beneath the reactor is a wire mesh which supports the material and allows the required air needed for gasification to flow into the material contained in the reactor.

\subsection{Design of Reactor}

The design equations required for the biomass cook-stove has been outlined by [23]. The energy required to be supplied by the stove, which is also the energy required to cook an amount of food or boil an amount of water, was determined from:

$$
Q=\frac{M_{f} \times E_{S}}{T}
$$

The energy required is $Q(\mathrm{kCal} / \mathrm{hr})$; the mass of food is $\mathrm{M}_{\mathrm{f}}(\mathrm{kg})$; the specific energy is $\mathrm{E}_{\mathrm{s}}(\mathrm{kCal} / \mathrm{kg})$; the time required to cook is $\mathrm{T}(\mathrm{hr})$. The fuel consumption rate, FCR $(\mathrm{kg} / \mathrm{hr})$ is a function of the energy required $\mathrm{Q}$, the heating value of the fuel, $\mathrm{H}_{\mathrm{f}}$ and the efficiency of the gasifier, $\mu_{\mathrm{g}}$ :

$$
F C R=\frac{Q}{H_{f} \mu_{g}}
$$

The diameter, $\mathrm{D}$, of the cross-section of the reactor is estimated from:

$$
D=\left(\frac{1.27 F C R}{S G R}\right)^{0.5}
$$

SGR $\left(\mathrm{kg} / \mathrm{m}^{2} \mathrm{hr}\right)$ is the specific gasification rate of the biomass material. The height of the reactor is estimated from:

$$
H=\frac{S G R \times T}{\rho}
$$

The density of the biomass material is $\rho\left(\mathrm{kg} / \mathrm{m}^{3}\right)$ and $\mathrm{T}(\mathrm{hr})$ is the time required to exhaust the biomass material in the reactor which is also the time required for cooking.

The rate of flow of air, AFR $\left(\mathrm{m}^{3} / \mathrm{hr}\right)$, needed for gasification of the biomass material in the reactor is determined from: 


$$
A F R=\frac{\epsilon \times F C R \times S A}{\rho_{a}}
$$

The equivalence ratio is $\epsilon$ and SA ( $\mathrm{kg}$ of air $/ \mathrm{kg}$ of biomass) is the stoichiometric air of the biomass material. The time taken, $\mathrm{T}$, to completely gasify the biomass material in the reactor is:

$$
T=\frac{\rho \times V_{r}}{F C R}
$$

The volume of the reactor in $\mathrm{m}^{3}$ is $\mathrm{V}_{\mathrm{r}}$. The velocity of air, $\mathrm{v}_{\mathrm{s}}$, moving through the bed of biomass material is:

$$
v_{s}=\frac{4 \times A F R}{\pi D^{2}}
$$

\subsection{Design of Burner}

An open-type burner has been designed for the cook-stove. The secondary air mixes with the syngas at the burner by natural draft. The burner was designed based on equations presented by [25]. The volume flow rate of air in the burner is estimated from:

$$
V_{a}=C A \sqrt{\frac{2 g h\left(T_{H}-T_{a}\right)}{T_{a}}}
$$

$\mathrm{C}$ is the loss coefficient to account for uncertainties and inefficiencies in the chimney effect, $\mathrm{g}$ is the acceleration due to gravity, $h$ is the height of the stove, $T_{H}$ is the temperature of hot gas, $T_{a}$ is the ambient temperature and $A$ is the flow area.

\subsection{Design Parameters of the Cook-stove}

Using the stated design equations, the design parameters for the developed cook-stove are stated in Table 1.

Table 1: Design parameters of the cook-stove

\begin{tabular}{ll}
\hline Parameter & Value \\
\hline Diameter of reactor & $170 \mathrm{~mm}$ \\
Height of reactor & $600 \mathrm{~mm}$ \\
Height of burner & $200 \mathrm{~mm}$ \\
Diameter of burner & $160 \mathrm{~mm}$ \\
Diameter of secondary air burner holes & $10 \mathrm{~mm}$ \\
Number of secondary air holes & 56 \\
Thickness of insulation & $100 \mathrm{~mm}$ \\
\hline
\end{tabular}

\section{EXPERIMENTAL METHODS}

\subsection{Materials}

The selected feedstocks utilized in the evaluation of the biomass cook-stove include corn cobs, palm kernel shells, coconut shells and wood chips. The corn cobs were collected from a maize processing firm. The palm kernel shell was collected from a palm oil processing firm. The wood chips were collected from a sawmill while the coconut shells were collected from a local vendor. The collected biomass materials were air dried for two weeks. The biomass cook-stove used is shown in Figure 1.

\subsection{Proximate Analysis}

The proximate analysis of the biomass materials was carried out to determine the volatile matter, fixed carbon and ash content. First each of the biomass materials were oven dried at a temperature of $110^{\circ} \mathrm{C}$ for 1 hour. To determine the volatile matter (VM), a mass of $2 \mathrm{~g}$ of each biomass material was placed in a crucible which was covered and heated in a furnace at $925^{\circ} \mathrm{C}$ for 7 minutes. The crucible was then cooled and the loss in weight was obtained. The percentage volatile matter is obtained as:

$$
\% V M=\frac{\text { loss in weight }}{\text { weight of dried biomass }} \times 100
$$




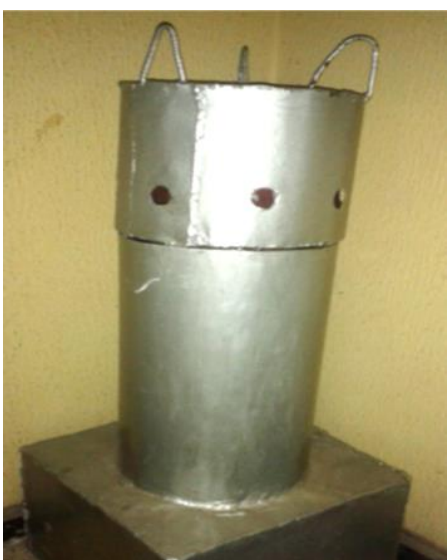

Figure 1: The inverted downdraft biomass gasifier

To determine the ash content (AC), $2 \mathrm{~g}$ of each dried biomass material was placed in an open crucible heated in a furnace at a temperature of $750^{\circ} \mathrm{C}$ for 30 minutes. After cooling, the weight of residue was obtained and the percentage ash content is:

$$
\% A C=\frac{\text { weight of residue }}{\text { weight of dried biomass }} \times 100
$$

The fixed carbon (FC) was determined from the volatile matter and ash content using:

$$
\% F C=100-(\% V M-\% A C)
$$

\subsection{Performance Evaluation of Cook-stove}

The performance evaluation of the inverted downdraft biomass gasifier cook-stove was carried out by weighing each biomass loaded into the cook-stove. The fuel was ignited and allowed to begin smooth operation which occurs after production of syngas is steady. The operating time of the cook-stove was recorded and the fuel consumption rate (FCR) of the cook-stove was obtained using:

$$
F C R=\frac{\text { mass of fuel used }}{\text { operating time }}(\mathrm{kg} / \mathrm{h})
$$

The specific gasification rate (SGR) was determined from:

$$
S G R=\frac{\text { Mass of fuel used }(\mathrm{kg})}{\text { Reator area }\left(\mathrm{m}^{2}\right) \times \text { Operating time }(\mathrm{hr})}
$$

Water boiling tests were carried out for each biomass material loaded into the biomass gasifier cook-stove. The time taken for 2 litres of water, whose mass was also determined, to reach boiling point was determined. The water was left to evaporate until the loaded fuel was exhausted. The water boiling test was used to determine the cook-stove efficiency as:

$$
\mu=\frac{m_{w i} c_{p w}\left(T_{e}-T_{i}\right)+m_{w e} H_{l}}{m_{f} H_{f}}
$$

Where $m_{w i}$ is the initial mass of water in the cooking vessel, $c_{p w}$ is the specific heat capacity of water, $m_{w e}$ is the mass of water evaporated, $m_{f}$ is the mass of fuel burned, $T_{e}$ is the temperature of boiling water, $T_{i}$ is the initial temperature of water in the vessel, $\mathrm{H}_{1}$ is the latent heat of evaporation of water and $\mathrm{H}_{\mathrm{f}}$ is the calorific value of the fuel. 
Frying tests and cooking tests were also carried out. For the frying test, $10 \mathrm{cl}$ of oil was poured into a frying pan and placed on the cook-stove. $10 \mathrm{~g}$ of fish was placed into the simmering oil and allowed to fry. Sensory tests were utilized to determine the end of the frying test.

For the cooking test, 2 litres of water were poured into a pot which was placed on the cook-stove, the water was allowed to boil and a $50 \mathrm{~g}$ of rice was poured into the boiling water with salt added to taste. Sensory tests were also relied upon to determine that the food had been satisfactorily cooked.

\section{RESULTS AND DISCUSSION}

\subsection{Proximate Analysis}

The results obtained for the proximate analyses of the different biomass material are presented in Table 2. Of the biomass materials analysed, wood chips had the lowest volatile matter and also the highest fixed carbon but also have the highest ash content. The values are within the range obtained for different species of wood by [26]. Generally, the heating values obtained for the biomass material showed that they have good combustion properties and a good potential for domestic cooking. Calorific values of biomass materials locally available in Nigeria has been compiled by [1].

Table 2: Proximate analysis of biomass materials

\begin{tabular}{lllll}
\hline Biomass & $\begin{array}{c}\text { Volatile } \\
\text { matter } \\
(\%)\end{array}$ & $\begin{array}{l}\text { Fixed } \\
\text { carbon } \\
(\%)\end{array}$ & $\begin{array}{l}\text { Ash } \\
\text { content } \\
(\%)\end{array}$ & $\begin{array}{l}\text { Heating } \\
\text { Value } \\
(\text { MJ/kg })\end{array}$ \\
\hline Wood chips & 74.03 & 21.37 & 4.60 & 17.0 \\
Corn cobs & 81.10 & 15.56 & 2.57 & 19.5 \\
Palm kernel shell & 85.70 & 11.80 & 2.50 & 15.0 \\
Coconut shell & 88.90 & 7.30 & 3.80 & 18.0 \\
\hline
\end{tabular}

\subsection{Performance Evaluation of Cook-stove}

The results for the water boiling test are presented in Figure 2. As observed, the heating rate for wood chips is higher followed respectively by the coconut shell palm kernel shell and corn cob. The time required for boiling varied for different biomass materials. Water boiled within 5.55 minutes when wood chips were used as fuel and at 7.30 minutes, 7.75 minutes and 8.72 minutes respectively when coconut shell, palm kernel shell and corn cobs were used as fuel in the biomass cook-stove.

The comparison of the averaged temperature of the biomass cook-stove with the three-stone stove and the kerosene stove is shown in Figure 3.

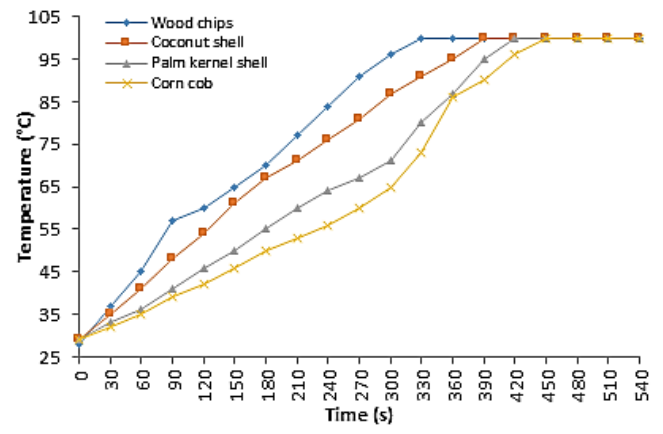

Figure 2: Results of the boiling test using different biomass as fuel

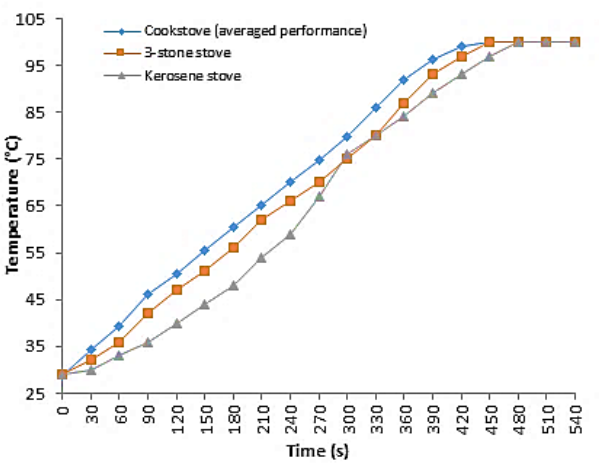

Figure 3: Comparison of the performance of the biomass cook-stove with a three-stone stove and kerosene stove

As observed, the biomass cook-stove had a better performance than the traditional three-stone stove and the kerosene stove. The results for the cooking test and frying tests for different biomass fuels are presented in Figure 4. From the tests carried out, wood chips had the lowest cooking and frying times followed respectively by coconut shell, palm kernel shell and corn cobs. The trend observed in the cooking and frying tests followed that of the boiling tests. From indications, there seems to be a correlation between the performance of the cook-stove and the biomass material used. 


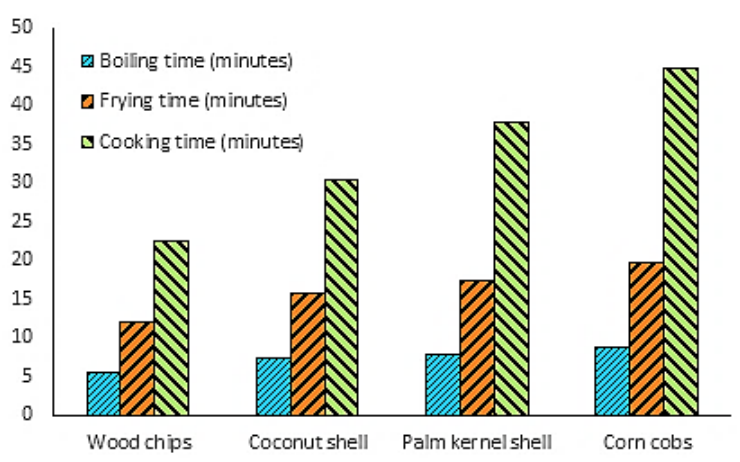

Figure 4: Comparison of the boiling, cooking and frying test using different biomass materials

The stove efficiency using different biomass feedstock as fuel is presented in Table 3. The stove efficiency varied with biomass materials with the least efficiency of $10.54 \%$ obtained when corn cobs are used as fuel. The maximum stove efficiency was determined to be $20.76 \%$ when wood chips were used as fuel. The cook-stove efficiencies for coconut shell and palm kernel shell were $16.85 \%$ and $15.85 \%$ respectively. Study by [22] reported that the performance of a top-lit updraft stove using wood chips as fuel was better than coconut shells which is in line with observations made in this study.

The fuel consumption rate of the cook-stove for utilization of the biomass fuels ranged between 1.60 to $1.82 \mathrm{~kg} / \mathrm{hr}$ with a mean value of $1.78 \mathrm{~kg} / \mathrm{hr}$. The specific gasification rate also ranged between 85.89 and $102.25 \mathrm{~kg} / \mathrm{m}^{2} \mathrm{hr}$ with a mean value of $97.75 \mathrm{~kg} / \mathrm{m}^{2} \mathrm{hr}$.

Table 3: Efficiency of biomass cook-stove using different biomass materials as fuel in the inverted downdraft biomass gasifier

\begin{tabular}{lll}
\hline Biomass used as fuel & $\begin{array}{l}\text { Efficiency of cook- } \\
\text { stove (\%) }\end{array}$ & \\
\hline Wood chips & 20.76 & \\
Coconut shell & 16.85 & \\
Palm kernel shell & 15.85 & \\
Corn cobs & 10.54 & \\
\hline
\end{tabular}

\section{CONCLUSION}

In this study, four biomass materials were characterized and used in evaluating the performance of an inverted downdraft biomass gasifier cook-stove. The biomass materials utilized were corn cobs, palm kernel shells, coconut shells and wood chips. The proximate analysis of the biomass fuels was determined. The performance evaluation showed that all biomass fuels examined were suitable for the operation of the cook-stove. The efficiency of the cook-stove was estimated to be $20.76 \%$ for wood chips, $16.85 \%$ for coconut shells, $15.85 \%$ for palm kernel shells and $10.54 \%$ for corn cobs. The fuel consumption rate of the cook-stove for utilization of the biomass fuels ranged between 1.60 to $1.82 \mathrm{~kg} / \mathrm{hr}$. The specific gasification rate also ranged between 85.89 and $102.25 \mathrm{~kg} / \mathrm{m}^{2} \mathrm{hr}$. Boiling tests, frying tests and cooking tests revealed that wood chips had the best performance while corn cobs had the least performance. The averaged performance of the cook-stove for all fuels revealed that the cook-stove performed better than the 3 -stone stove and the kerosene stove.

\section{REFERENCES}

[1] Ojolo, S. J., Orisaleye, J. I., Ismail, S. O. and Abolarin, S. M. Technical potential of biomass energy in Nigeria, Ife Journal of Technology, 2(2), 60-65, 2012.

[2] Kaygusuz, K. and Türker, M. F. Biomass energy potential in Turkey, Renewable Energy, 26(4), 661-78, 2002.

[3] Moreira, R. Global biomass energy potential, Mitigation and Adaptation Strategies for Global Change, 11(2), 313-33, 2006. 
[4] Omer, A. M. Biomass energy potential and future prospect in Sudan, Renewable and Sustainable Energy Reviews, 9(1), 1-27, 2005.

[5] Adria, O. and Bethge, J. What users can save with energy-efficient cooking stoves and ovens, Wuppertal Institute for Climate, Environment and Energy, Germany, 2013.

[6] World Health Organization, WHO (2014). Household air pollution and health, www.who.int/mediacentre/factsheets/fs292/en/

[7] Food and Agricultural Organization of the United Nations, FAO. Improved solid biomass burning cook-stoves: A development manual, Food and Agricultural Organisation of the United Nations, Bangkok, 1993.

[8] Olorunsola, A. O. The development and performance evaluation of a briquette burning stove". Nigerian Journal of Renewable Energy, 7(1), 91-95, 1999.

[9] Orisaleye, J. I., Jekayinfa, S. O., Adebayo, A. O., Ahmed, N. A. and Pecenka, R. Effect of densification variables on density of corn cob briquettes produced using a uniaxial compaction biomass briquetting press, Energy Sources, Part A: Recovery, Utilization, and Environmental Effects, 40(24), 3019-3028, 2018.

[10] Tumuluru, J. S., Wright, C. T., Kenny, K. L. and Hess, J. R. A technical review on biomass processing: Densification, preprocessing, modelling, and optimization, 2010 ASABE Annual International Meeting, Pittsburg, Pennsylvania, US, June 2010.

[11] Ojolo, S. J. and Orisaleye, J. I. Design and development of a laboratory scale biomass gasifier, Journal of Energy and Power Engineering, 4(8), 16-22, 2010.

[12] Jekayinfa, S. O., Linke, B. and Pecenka, R. Biogas production from selected crop residues in Nigeria and estimation of its electricity value, International Journal of Renewable Energy Technology, 6(2), 101-18, 2015.

[13] Ojolo, S. J., Orisaleye, J. I., Ismail, S. O. and Odutayo, A. F. Development of an inverted downdraft biomass gasifier cook-stove, Journal of Emerging Trends in Engineering and Applied Sciences, 3(3), 513-516, 2012.

[14] Sivaram, A. R., Karuppasamy, K., Rajavel, R. and Vikram, C. J. Performance analysis of an inverted downdraft biomass wood stove, International Journal of Mechanical Engineering Technology, 6(8), 144-155, 2015 .

[15] Bantelay, D. T. and Gabbiye, N. Design, manufacturing and performance evaluation of household gasifier stove: a case study of Ethiopia, American Journal of Energy Engineering, 2(4), 96-102, 2014.

[16] Ayo, S. A. Design, construction and testing of an improved wood stove, AU Journal of Technology, 13(1), 12-18, 2009.

[17] Thakur, L. K., Sonkaskar, Y. M., Waghmare, S. S., Duryodhan, N. S. and Arfin, T. Fabrication and performance analysis of a biomass cook-stove, International Journal for Scientific Research and Development, 3(6), 440-445, 2015.

[18] Sultan, K. and Ahmad, M. Energy efficient biomass gasifier stove for domestic purpose, Journal of Energy Technologies and Policy, 5(10), 72-84, 2015.

[19] Bello, R. S., Onilude, M. A. and Adegbulugbe, T. A. Design and performance evaluation of supplemental air supplied charcoal stove, International Letters of Chemistry, Physics and Astronomy, 54(1), 1-10, 2015.

[20] Tryner, J., Marchese, A. J. and Wilson, B. D. The effects of fuel type and geometry on emissions and efficiency of natural draft semi-gasifier biomass cook-stoves, Coal and Biomass Combustion and Gasification, 8th U.S. National Combustion Meeting, University of Utah, paper 070CO-0078, 2013. 
[21] Kornelius, G., Kruger, S., Fouchee, R. and Wyk, H. A wood gasification stove for domestic use: design, performance and emission factors, Clean Air Journal, 22(2), 14-16, 2012.

[22] Obi, O. F., Ezeoha, S. L. and Okorie, I. C. Energetic performance of a top-lit updraft (TLUD) cook-stove, Renewable Energy, 99, 730-737, 2016.

[23] Belonio, A. T. Rice husk gas stove handbook, Appropriate Technology Centre, Department of Agricultural Engineering and Environmental Management, College of Agriculture, Central Philippine University, Iloilo City, Philippines, 2005.

[24] Raman, P., Murali, J., Sakthivadivel, D. and Vigneswaranm, V. S. Evaluation of domestic cook-stove technologies implemented across the world to identify possible options for clean and efficient cooking solutions, Journal of Energy and Chemical Engineering, 1(1), 15-26, 2013.

[25] Kumar, M., Kumar, S. and Tyagi, S. K. Design, development and technological advancement in the biomass cook-stoves: a review, Renewable and Sustainable Energy Reviews, 26, 265-285, 2013.

[26] Adegoke, O. A., Fuwape, J. A. and Fabiyi, J. S. Combustion properties of some tropical wood species and their pyrolytic products characterization, Energy and Power, 4(3), 54-57, 2014. 